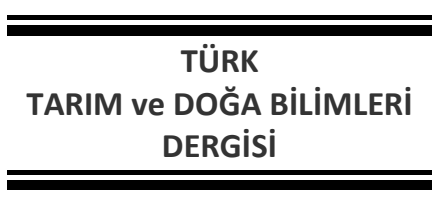

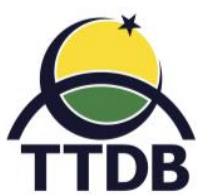

www.dergipark.gov.tr/turkjans

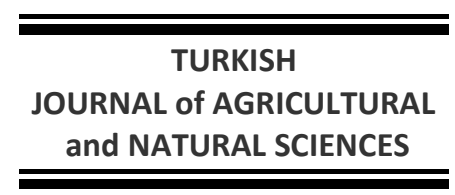

Araştırma Makalesi

\title{
Amsonia orientalis'de 6-Benzilaminopürin Destekli In vitro Sürgün Çoğaltımı Üzerine Kuraklık Stresinin Morfolojik ve Fizyolojik Etkileri
}

\author{
Arda ACEMi' ${ }^{*}$, Halil TOYGAR ${ }^{1}$, Yonca YÜZÜGÜLLÜ KARAKUŞ ${ }^{1}$, Yonca AVCI DUMAN² ${ }^{2}$ Fazıl ÖZEN ${ }^{1}$ \\ ${ }^{1}$ Kocaeli Üniversitesi, Fen - Edebiyat Fakültesi, Biyoloji Bölümü, Kocaeli \\ ${ }^{2}$ Kocaeli Üniversitesi, Fen - Edebiyat Fakültesi, Kimya Bölümü, Kocaeli \\ *Sorumlu yazar: arda.acemi@kocaeli.edu.tr
}

Geliş Tarihi: 09.10.2018

Düzeltme Geliş Tarihi: 19.03.2019

Kabul Tarihi: 24.06.2019

Özet

Bu çalışmada Amsonia orientalis Decne.'nin 6-benzilaminopürin (BAP) destekli in vitro sürgün çoğaltımı aşamasında uygulanmış kuraklık stresi etkisinin morfolojik ve bazı fizyolojik etkileri incelenmiştir. Kültürlerin inkübasyon sürelerinin sonunda sürgünlerin ortalama uzunluk ve sayıları, $\mathrm{H}_{2} \mathrm{O}_{2}$ (hidrojen peroksit) ve MDA (malondialdehit) seviyeleri ile SOD (süperoksit dismutaz), POD (peroksidaz) ve CAT (katalaz) enzimlerinin aktiviteleri analiz edilmiştir. Polietilen glikol (PEG-6000) kullanılarak elde edilen -0,15, -0,49, -1,03 ve -1,76 MPa osmotik potansiyeller sürgünler üzerinde BAP ilaveli ve ilavesiz olmak üzere iki kontrol grubu kullanılarak test edilmiştir. Ortalama sürgün sayısı düşen osmotik potansiyelle birlikte BAP ilaveli kontrole kıyasla azalsa da BAP ilavesiz kontrol değeriyle istatistiki olarak aynı düzeyde kalmıştır. Ortalama sürgün uzunluğu ise sadece en şiddetli kuraklık uygulaması sonucu BAP ilavesiz kontrol değerinin altına düşmüştür. SOD aktivitesi artan kuraklığa bağlı olarak kontrol değerlerine göre önemli ölçüde azalırken şiddetli kuraklıkta kontrol değerine kadar yükselmiştir. POD ve CAT aktivitelerinde de düşüş gözlenmiş ancak CAT aktivitesindeki azalmanın daha belirgin olduğu görülmüştür. Artan kuraklık etkisinde $\mathrm{H}_{2} \mathrm{O}_{2}$ ve MDA seviyelerinin benzer olarak arttığı bulunmuştur. Buna karşın bu artış düşük seviyelerde gerçekleşmiştir. Kuraklık stresi uygulanmamışken antioksidan enzim aktivitelerinin daha yüksek bulunması fakat düşen osmotik potansiyellerde beklenenin aksine azalması durumu $A$. orientalis'te BAP uygulamasının hücresel osmotik düzenleyicilerin görev aldığı enzimatik olmayan savunma mekanizmasını uyardığını ve daha etkin kullanılmasına imkân verdiği sonucunu düşündürmüştür. Bu nedenle bitkide kuraklık stresinde BAP uygulamasının moleküler ve fizyolojik işleyişinin detaylı olarak ortaya konması gerekmektedir. BAP uygulaması doğada $A$. orientalis'in kuraklık stresine maruz kalması durumunda kuraklığın sürgünler üzerindeki olası olumsuz etkilerini hafifletmek için tercih edilebilir.

Anahtar kelimeler: Amsonia orientalis, 6-benzilaminopürin, katalaz, kuraklık stresi, peroksidaz, süperoksit dismutaz.

\section{Morphological and Physiological Effects of Drought Stress on 6-Benzylaminopurine-Assisted In vitro Shoot Multiplication in Amsonia orientalis}

\footnotetext{
Abstract

In this study, the morphological and physiological effects of drought stress on Amsonia orientalis Decne. were investigated during 6-benzylaminopurine (BAP) -assisted in vitro shoot multiplication. At the end of the incubation period, mean shoot lengths and numbers, $\mathrm{H}_{2} \mathrm{O}_{2}$ (hydrogen peroxide) and MDA (malondialdehyde) levels and the activities of SOD (superoxide dismutase), POD (peroxidase) and CAT (catalase) enzymes were analyzed. The osmotic potentials of $-0.15,-0.49,-1.03$, and $-1.76 \mathrm{MPa}$ obtained using polyethylene glycol (PEG-6000) were tested
} 
on shoots, and the results were compared with two control groups, with and without BAP. Although the mean number of shoots declined with decreasing osmotic potential compared to control with BAP, it remained at the statistically same level with control without BAP. The mean shoot length was found to be lower than that of the control without BAP in response to the severe drought application. SOD activity showed a significant reduction compared to control values in response to mild drought. However, the activity increased up to the control values in severe drought. POD and CAT activities also decreased under drought while the decrease in CAT activity was more pronounced. $\mathrm{H}_{2} \mathrm{O}_{2}$ and MDA levels were found to be increased similarly with elevated drought stress. However, this increase was found to be limited to low levels. The presence of higher antioxidant enzyme activities in the absence of drought stress but unexpected lower activities in lower osmotic potentials (during drought stress) suggested that the application of BAP in A. orientalis may stimulate the non-enzymatic defense mechanism which employs the cellular osmotic regulators, and it may allow this mechanism to be used more efficiently than enzymatic defense system. For this reason, the molecular and physiological functioning of BAP application in plant drought stress needs to be explained in detail. Also, BAP application may be preferred to alleviate the potential adverse effects of drought stress on shoots of $A$. orientalis in nature.

Key words: Amsonia orientalis, 6-benzylaminopurine, catalase, drought stress, peroxidase, superoxide dismutase.

\section{Giriş}

Amsonia orientalis Decne. (Apocynaceae) ülkemizin kuzeybatı, Yunanistan'ın ise kuzeydoğu kesimlerinde doğal yayılış gösteren ve Uluslararası Doğayı Koruma Birliği (IUCN)'nin “Çok tehlikede” (Critically endangered; CR) kategorisinde sınıflandırdığı bir bitki türüdür (Acemi ve ark., 2013). Tabiatta doğal olarak bulunabilmesinin yanı sıra süs bitkisi olarak çeşitli ülkelerde sınırlı sayıda kültüre alınmıştır (Acemi ve ark., 2012). Süs bitkisi olarak değerinin dışında, içerdiği kardiyak glikozitler ve Picralinal, Tabersonine, Secamine gibi tümör ve kanser karşıtı etkileri ile bilinen sekonder metabolitleri içerdiği için tıbbi olarak da değerlidir (Acemi ve ark., 2017a). Bu ekolojik ve ekonomik nedenlerden dolayı $A$. orientalis'in öncelikli olarak doğada korunması ve mevcut tükenme tehlikesine karşı önlem alınması gereklidir. Doğal popülasyonları azalma eğiliminde olan benzer bitki türlerinin korunması için bitki doku kültürü tekniği mevsimden bağımsız uygulanabilirliği ve kısa sürede yüksek sayıda bitki eldesi gibi avantajlı yönleriyle tercih edilmektedir (George 2008). A. orientalis'in Türkiye'deki popülasyonlarının sadece İstanbul, Balıkesir ve Bursa illerinden bildirilmesine rağmen günümüzde bu yayılışın sadece Balıkesir ilinde yaklaşı $10 \mathrm{~km}^{2}$ boyutunda bir alanda 4 ayrı popülasyon olarak sınırlı kalması doku kültürü tekniğinin bu bitkinin hızlıca çoğaltılmasının yanı sıra yayılış alanındaki daralmanın nedeni olabilecek çeşitli abiyotik stres faktörlerine karşı da direnç seviyesinin anlaşılmasında kullanılabileceğini göstermiştir (Gürkanlı ve ark., 2014, Acemi ve ark., 2018).

Küresel ısınma ile birlikte artan kuraklık bitki büyümesini etkileyen en önemli abiyotik faktörlerden biridir. Bu etki verimin azalması, bitki büyümesindeki çeşitli olumsuzluklar ve buna bağlı olarak görece kuraklığa toleranslı olmayan türlerin yaşam alanlarının daralması şeklinde ortaya çıkabilir (Wu ve ark., 2012). Çeşitli stres faktörlerinin bitkilerde meydana getirdiği etkilerden biri de fizyolojik süreçlerdeki değişimlerdir. Çeşitli stres faktörleri karşısında bitkilerde genel bir tepki olarak süperoksit $\left(\mathrm{O}_{2}{ }^{-}\right)$ve hidroksil $\left(\mathrm{OH}^{\circ}\right)$ radikallari, singlet oksijen $\left({ }^{1} \mathrm{O}_{2}\right)$ ve hidrojen peroksit $\left(\mathrm{H}_{2} \mathrm{O}_{2}\right)$ gibi reaktif oksijen türlerinin (ROS) oluşumunun tetiklendiği bilinmektedir (Duman ve ark., 2016). Bitkiyi ROS oluşumunun zararlı etkilerinden korumak için antioksidan enzimlerden katalaz (CAT), süperoksit dismutaz (SOD) ve peroksidazlar (POD) etkileşim içinde çalışırlar. Bu zararlı etkilerden en belirgini hücre zarı lipitlerinin peroksidasyonu yoluyla hücreye verilen hasardır. Bu noktada, oluşan malondialdehit (MDA) miktarının ölçülmesi bitkideki hücresel hasarın düzeyi ile ilgili bir belirteç olabilir (Skórzyńska-Polit 2007).

Sürgün rejenerasyonu in vitro kültürlerde genellikle sitokininlerin varlığında, sürgünlerin nodlarından veya apikal meristemden yeni sürgün oluşumunu ifade eder ve sürgün çoğaltımı için sıkça kullanılan stratejilerden biridir. Bu bağlamda en yaygın kullanılan sitokininlerden birisi 6benzilaminopürin (BAP)'dir. A. orientalis'te de bu sitokininin besiyerinde $1 \mathrm{mg} \mathrm{l}^{-1}$ konsantrasyonda kullanılmasının yanal dallanmayı kuvvetle uyardığı bildirilmiştir (Acemi ve ark., 2013). Aynı zamanda BAP'ın tuz ve kuraklık streslerinin bitki gelişiminde ortaya çıkardığı olumsuz etkileri yatıştırdığı da bilinmektedir (Rulcová ve Pospišilová 2001, Gurmani ve ark., 2011). Bu çalışmanın amacı kuraklık stresi altındaki $A$. orientalis sürgünlerinin nodlarından BAP destekli yanal sürgün rejenerasyonunun biyokimyasal 
ve morfometrik açıdan değerlendirilmesi ve bu sayede BAP'ın kuraklık stresine maruz kalan $A$. orientalis sürgünlerinin canlılığını sürdürmesine yapabileceği potansiyel katkının belirlenmesidir.

\section{Materyal ve Yöntem \\ Sürgünlerin in vitro çoğaltımı ve kuraklık stresinin oluşturulması}

Sürgünler Kocaeli Üniversitesi, Umuttepe Kampüsü'ndeki koruma parselinde bulunan anaç Amsonia orientalis bitkilerinden çiçeklenme dönemi öncesinde alınmıştır. Bitkilerden alınan sürgünler yapraklarından arındırılarak tek nod içeren parçalara ayrılmış ve ardından musluk suyu altında yıkanmıştır. Yüzeysel sterilizasyon için eksplantlar önce 2 dakika $\% 70$ (v/v) EtOH ardından 10-12 dakika boyunca \%1 (v/v) $\mathrm{NaOCl}$ içerisinde bekletilmiştir. Steril distile $\mathrm{H}_{2} \mathrm{O}$ içerisinde durulandıktan sonra $1 \mathrm{mg} \mathrm{l}^{-1}$ BAP içeren Murashige ve Skoog (MS) (1962) sürgün çoğaltım ortamına ekilmiştir. Bu işlem sonucunda elde edilen in vitro sürgünlerin nodları kuraklık stresi denemelerinde kullanılmıştır.

Bu nodal eksplantlar $1 \mathrm{mg} \mathrm{l}^{-1}$ BAP içeren ve polietilen glikol (PEG-6000) çözeltisi aracılığıyla -0,15, $-0,49,-1,03$ ve $-1,75 \mathrm{MPa}$ osmotik basınç oluşturulmuş MS besi ortamında kültüre alınmışlardır (Mohammadkhani ve Heidari 2008). Denemelerde 1 $\mathrm{mg} \mathrm{l}^{-1}$ BAP ilaveli ve ilavesiz olmak üzere iki adet kontrol grubu kullanılmıştır. Besiyerinin $\mathrm{pH}$ derecesi 5,7 olarak ayarlanmış ve besiyeri $30 \mathrm{~g} \mathrm{l}^{-1}$ sukroz ve $7 \mathrm{~g}$ $\mathrm{I}^{-1}$ agar ile desteklenmiştir. Kültürler bitki büyütme kabininde $80 \mu \mathrm{mol} \mathrm{m} \mathrm{m}^{-2} \mathrm{~s}^{-1}$ fotosentetik foton akı yoğunluğundaki ışık altında $16 / 8$ sa ışıklandırma periyodunda, $23 \pm 1{ }^{\circ} \mathrm{C}^{\prime}$ de tutulmuşlardır.

\section{Ham ekstraktın hazırlanması}

Biyokimyasal analizleri gerçekleştirmek için kuraklık stresi ve BAP varlığında rejenere olan sürgünlerden ham ekstraktlar Acemi ve ark. (2017b)'na göre hazırlanmıştır. Buna göre dokular 20 katı hacimdeki $50 \mathrm{mM}$ sodyum fosfat $(\mathrm{pH} 7,0)$ tampon ile homojenize edildikten sora filtre kâğıdından süzülmüştür. Ardından bu süzüntü 15000 $\times$ g kuvvetle $4{ }^{\circ} C^{\prime}$ de 15 dakika boyunca santrifüj edilmiştir. Elde edilen üst faz biyokimyasal parametrelerin ölçülmesinde kullanılmıştır.

\section{Antioksidan enzim aktivitelerinin belirlenmesi}

Artan kuraklık stresi ve BAP varlığında antioksidan enzim aktiviteleri (SOD; süperoksit dismutaz, E.C. 1.15.1.1., POD; peroksidaz, E.C. 1.11.1.X, CAT; katalaz, E.C. 1.11.1.6) spektrofotometrik olarak belirlenmiştir. SOD aktivitesi NBT (nitro blue tetrazolium)'nin fotokimyasal indirgenmesinin $560 \mathrm{~nm}$ 'de ölçülmesi ile belirlenmiştir (Beauchamp ve Fridovich 1973). Bir ünite SOD aktivitesi bu indirgenmenin \%50 inhibisyonunu sağlayan enzim miktarı olarak tanımlanmıştır (Yüzügüllü Karakuş ve ark., 2018). POD aktivitesi pirogallol oksidasyon sonucu oluşan purpurogallin miktarı dikkate alınarak incelenmiştir (Targovnik ve ark., 2012). Enzim aktivitesi 420 nm'de fosfat tampon içinde pirogalol için $\varepsilon$ (ekstinksiyon katsayısı) $2640 \mathrm{M}^{-1} \mathrm{~cm}^{-1}$ alınarak hesaplanmış (Valetti ve Picó 2013) ve 5 dakikada $1 \mathrm{mg}$ purpurogalin oluşması için gerekli olan enzim miktarı olarak tanımlanmıştır (Yüzügüllü Karakuş ve ark., 2018). CAT aktivitesi ise $240 \mathrm{~nm}$ 'de ölçülen $\mathrm{H}_{2} \mathrm{O}_{2}$ absorbansının azalması takip edilerek ölçülmüştür (Yüzügüllü Karakuş ve ark., 2018). Bir ünite enzim aktivitesi 1 $\mu \mathrm{mol} \mathrm{H}_{2} \mathrm{O}_{2}$ parçalanması için gerekli olan enzim miktarı olarak tanımlanmıştır $\left(\mathrm{H}_{2} \mathrm{O}_{2}\right.$ için $\varepsilon$ değeri $0,039 \mathrm{~cm}^{2} \mu \mathrm{mol}^{-1}$ ) (Aebi 1974). Tüm örnekler için protein miktarı Bradford (1976)'a göre belirlenmiştir.

\section{Lipid peroksidasyonun ve $\mathrm{H}_{2} \mathrm{O}_{2}$ içeriğinin belirlenmesi}

Lipid peroksidasyonu sonucunda oluşan malondialdehit (MDA) miktarının belirlenmesiyle kuraklık stresi sonucunda meydana gelen hücresel hasarın boyutu belirlenmiştir (Turan ve Tripathy 2013). MDA içeriğinin analizi Duman ve ark. (2016)'na göre spektrofotometrik olarak gerçekleştirilmiş ve elde edilen örneklerin absorbansları 532 ve $600 \mathrm{~nm}^{\prime}$ de kaydedilmiştir. MDA içeriği $\varepsilon$ değeri $156 \mathrm{mM}^{-1} \mathrm{~cm}^{-1}$ alınarak aşağıdaki formülden hesaplanmıştır.

MDA miktarı $\left(\mu \mathrm{mol} \mathrm{g}{ }^{-1}\right)=\left[\left(A_{532}-A_{600}\right) / 156\right] \times$ $10^{3} \times$ Seyreltme faktörü

$\mathrm{H}_{2} \mathrm{O}_{2}$ içeriği elde edilen özütün potasyum iyodür (KI) ile reaksiyonu sonrası spektrofotometrik olarak ölçülmüştür (Duman ve ark., 2016). $\mathrm{H}_{2} \mathrm{O}_{2}$ içeriğini hesaplamak için önceden tanımlanmış $\mathrm{H}_{2} \mathrm{O}_{2}$ konsantrasyonlarında standart eğri hazırlanmıştır (Doupis ve ark., 2011).

\section{istatistiksel analiz}

Denemeler tesadüf parselleri deneme desenine göre kurulmuş olup her uygulama için kültür kabı başına 5 eksplant olacak şekilde toplam 30 eksplant kullanılmış ve deneyler üç kez tekrarlanmıştır. Kültürlerin inkübasyon süresi 30 gün olarak belirlenmiş ve ölçümler bu periyodun sonunda yapılmıştır. Veriler arasındaki istatistiksel farklılığın 
derecesi Duncan çoklu karşılaştırma testi $(p<0.05)$ 'ne göre belirlenmiştir. İstatistiksel analiz IBM SPSS Statistics 19 programı kullanılarak gerçekleştirilmiştir.

\section{Bulgular ve Tartışma}

Kültür periyodunun sonunda uygulanan kuraklık denemeleri sonucunda BAP ilaveli kontrole oranla ortalama sürgün uzunlukları ve sayıları azalmıştır. Buna karşın -1,76 MPa osmotik potansiyele sahip besiyeri ve BAP ilavesiz kontrolden elde edilen ortalama sürgün sayısı verileri istatistiki olarak benzer bulunmuştur. Morfometrik sonuçlardan anlaşılacağı üzere kuraklık stresi süresince yapılan BAP uygulaması sürgün sayısı (Şekil $1 A)$ ve sürgün uzunluğu (Şekil $1 B$ ) verilerinin $B A P$ ilavesiz kontrolün üzerinde kalmasına yardımcı olmuştur. Kuraklık stresinde bitki büyümesinin yavaşlaması ve durması gibi morfolojik etkiler sürgün ve kök meristemlerindeki hücrelerin bölünmesi ve uzamasının durması ve/veya yavaşlaması sonucunda ortaya çıkmaktadır (Anjum ve ark., 2011). Ayrıca kuraklık neticesinde ksilemden su aktarımının aksaması da bu durumu tetiklemektedir. Buna karşın bitki hücreleri osmotik potansiyellerini düşürerek turgor durumlarını muhafaza etmeye çalışırlar (Farooq ve ark., 2009). Ksilemden sağlanan aktarımın sürgünlerdeki sitokinin içeriğinin kontrolünde indol3-asetik asit (IAA) ile birlikte bir rolü olabileceği bildirilmiştir (Kotov ve Kotova, 2015). Morfometrik ölçümlerden elde edilen sonuçlar bu bağlamda BAP uygulamasının kuraklık stresi altındaki sürgünlerde turgorun ve ksilem aktarımının muhafazasına katkıda bulunduğu şeklinde yorumlanabilir. Benzer sonuçlar dış kaynaklı sitokinin uygulaması neticesinde tuz stresi altındaki $A$. orientalis'de (Duman ve ark., 2016) ve sitokinin içeriğinin modülasyonu sonrasında kuraklık stresi altındaki Nicotiana tabacum'da gösterilmiştir (Rivero ve ark., 2007).
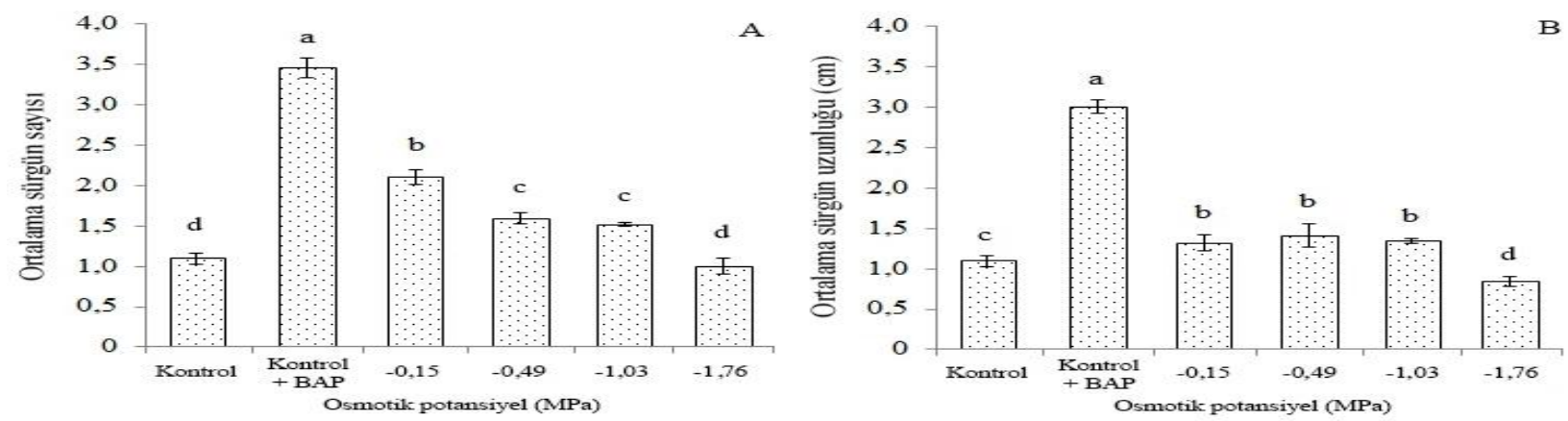

Şekil 1. Artan kuraklık stresi koşullarının A. orientalis'de $1 \mathrm{mg} \mathrm{l}$ l-1 $^{-}$BAP destekli sürgün çoğaltımı sırasında ortalama sürgün sayısı (A) ve uzunluğuna (B) etkileri. Hata çubukları standart sapmayı ifade etmektedir. Aynı harfleri taşıyan değerler arasında Duncan çoklu karşılaştırma testine göre istatistiki fark yoktur $(p<0,05)$.

Çizelge 1. Artan kuraklık stresi koşullarında $A$. orientalis sürgünlerinde (1 $\mathrm{mg} \mathrm{l}^{-1}$ BAP varlığında) $S O D, P O D$ ve CAT aktivitelerinde gözlenen değişimler

\begin{tabular}{cccc}
\hline Osmotik potansiyel (MPa) & SOD aktivite $\left(\mathbf{U ~ m g}^{-1}\right)$ & POD aktivite $\left(\mathbf{U ~ m g}^{-1}\right)$ & CAT aktivite $\left(U \mathbf{~ m g}^{-1}\right)$ \\
\hline Kontrol & $0,75 \pm 0,03^{\mathrm{a}}$ & $0,64 \pm 0,03^{\mathrm{a}}$ & $0,32 \pm 0,01^{\mathrm{a}}$ \\
Kontrol + BAP & $0,74 \pm 0,02^{\mathrm{a}}$ & $0,66 \pm 0,01^{\mathrm{a}}$ & $0,32 \pm 0,01^{\mathrm{a}}$ \\
$-0,15$ & $0,35 \pm 0,03^{\mathrm{c}}$ & $0,60 \pm 0,01^{\mathrm{b}}$ & $0,29 \pm 0,03^{\mathrm{b}}$ \\
$-0,49$ & $0,25 \pm 0,02^{\mathrm{d}}$ & $0,51 \pm 0,02^{\mathrm{c}}$ & $0,20 \pm 0,03^{\mathrm{c}}$ \\
$-1,03$ & $0,22 \pm 0,02^{\mathrm{d}}$ & $0,43 \pm 0,03^{\mathrm{d}}$ & $0,18 \pm 0,03^{\mathrm{d}}$ \\
$-1,76$ & $0,62 \pm 0,05^{\mathrm{b}}$ & $0,40 \pm 0,02^{\mathrm{d}}$ & $0,18 \pm 0,02^{\mathrm{d}}$ \\
\hline
\end{tabular}

Bir değere ait kolondaki farklı harfler, Duncan çoklu karşılaştırma testine göre istatistiksel olarak ortalamalar arasındaki önemli farklılıkları göstermektedir $(p<0,05)$. Standart sapma $( \pm S S)$.

Kuraklığa karşı antioksidan enzimlerin BAP varlığında gösterdikleri aktivitelerindeki değişimler Çizelge 1'de gösterilmiştir. Artan osmotik potansiyel baskısının tetiklediği su alımının kısıtlanması sürgünlerdeki $S O D, P O D$ ve $C A T$ enzimlerinin aktivitelerinde değişimlere neden olmuştur. En belirgin değişim SOD enzimi üzerinde görülmüştür. SOD enzim aktivitesi düşen osmotik potansiyelle birlikte gerilemiş ve kontrol değerlerinin altında seyretmiştir. Buna karşın -1,76 MPa osmotik potansiyelde SOD aktivitesi kontrol değerlerine yaklaşmıştır. Öte yandan POD aktivitesinde de benzer 
bir durum gözlenmiş olup aktivitedeki bu düşüş $-0,49$ MPa ve sonraki osmotik potansiyellerde gözlenmiştir. Bununla birlikte $-1,03$ ve $-1,76 \mathrm{MPa}$ osmotik potansiyel uygulamalarından elde edilen sonuçlar arasında istatistiki fark bulunmamıştır. CAT aktivitesindeki düşüş dikkat çekici olarak $-0,49$ ve sonraki osmotik potansiyellerde gözlenmiştir. POD verilerine benzer olarak uygulanan en düşük iki osmotik potansiyelden elde edilen sonuçlar istatistiki olarak benzerdir. SOD birincil görev olarak süperoksit radikallerini moleküler oksijen $\left(\mathrm{O}_{2}\right)$ veya $\mathrm{H}_{2} \mathrm{O}_{2}$ 'ye dönüştürürken, askorbat-glutatyon döngüsünde yer alan enzimler de $\mathrm{H}_{2} \mathrm{O}_{2}$ 'nin aşırı birikmesini önler. $\mathrm{Bu}$ çalışmadaki bulgulara benzer olarak kuraklık şartlarında Calendula officinalis bitkisinde $40 \mu \mathrm{M}$ BAP uygulaması sonucunda SOD aktivitesinin azaldığı rapor edilmiştir (Sedghi ve ark., 2012). POD ve CAT ise bitkilerde reaktif oksijen türlerini (ROS) $\mathrm{O}_{2}$ ve $\mathrm{H}_{2} \mathrm{O}^{\prime}$ ya parçalayan antioksidan enzimler olup $A$. orientalis'in antioksidan savunma sisteminde ortaklaşa çalıştıkları gösterilmiştir (Acemi ve ark., 2017b). POD enzim aktivitesinin düşen osmotik potansiyele paralel tepki vermesi SOD aktivitesinin önemli derecede düşüşüyle açıklanabilir. Buna rağmen CAT aktivitesinin en düşük osmotik potansiyelde dahi yükselmemesi BAP'ın ROS üretimini baskılayıcı etkisinin yanı sıra CAT enzimine bağlanıp enzim aktivitesini inhibe edebilme kabiliyetine de atfedilebilir (Xu ve ark., 2014). Kuraklık stresinin $A$. orientalis'in antioksidan enzimleri üzerindeki etkilerinin analiz edildiği başka bir çalışmada ise SOD ve POD enzim aktivitelerin kuraklığa son derece duyarlı oldukları belirlenmiş ve özellikle POD aktivitesinin artan kuraklık stresinde kontrol grubuna oranla önemli ölçüde yükseldiği gösterilmiştir (Acemi ve ark., 2018). Bu çalışmada ise POD ve CAT enzimlerinin artan kuraklık stresiyle birlikte görece düşük seyri BAP'ın stresin olumsuz etkilerini yatıştırmakta yardımcı olduğunu, SOD’un ise şiddetli kuraklıkta yükselmesi diğer iki antioksidan enzime göre BAP varlığında daha baskın rol oynayabileceğine işaret etmektedir.

MDA stres koşullarında ROS üretiminin artması sonucu hücre zarı lipitlerinde oluşan hasarın derecesinin belirlenmesinde kullanılan bir belirteçtir.
$\mathrm{Bu}$ çalışmada MDA miktarının düşen osmotik potansiyelle birlikte arttığı görülmüştür (Şekil 2A). Buna rağmen $-0,15 \mathrm{MPa}$ uygulaması sonucunda kontrole yakın bir MDA içeriği bulunmuştur. En yüksek değer -1,76 $\mathrm{MPa}$ uygulamasından elde edilmiştir. Kumari ve ark. (2018) dışarıdan BAP uygulamasının kuraklık stresi altındaki buğdayda lipid peroksidasyonunu ve nispi su kaybını hafiflettiği ve hücre zarı kararlılığını artırdığını göstermişlerdir. İstatistiki olarak farklı olsa da düşük artışlarla yükselen fakat nispeten düşük seviyelerde seyreden MDA içeriği BAP uygulamasının bu özelliğine atfedilebilir. Aynı koşullarda BAP varlığında uygulanan UV-C ve tuz streslerinde de benzer MDA grafikleri elde edilmiştir (Duman ve ark., 2016; Yüzügüllü Karakuş ve ark., 2018). Reaktif oksijen türlerinden biri olan $\mathrm{H}_{2} \mathrm{O}_{2}$ aynı zamanda bitki savunma mekanizmasında bir sinyal molekülü olarak görev alır. Artan kuraklık stresiyle birlikte $\mathrm{H}_{2} \mathrm{O}_{2}$ seviyelerinde de artış gözlenmiştir (Şekil 2B). BAP ilaveli kontrol grubunda ise diğer kontrol grubuna göre $\mathrm{H}_{2} \mathrm{O}_{2}$ üretimi azalmıştır. BAP ilavesiz kontrol ile $0.15 \mathrm{MPa}$ osmotik potansiyel uygulaması sonuçları istatistiki olarak benzerdir. Kuraklık stresi altındaki $A$. orientalis'de BAP uygulanmadığı zaman bu çalışmadaki verilere oranla daha fazla $\mathrm{H}_{2} \mathrm{O}_{2}$ üretildiği gösterilmiştir (Acemi ve ark., 2018). Aşırı $\mathrm{H}_{2} \mathrm{O}_{2}$ üretimi nedeniyle kuraklık stresi altında hücresel redoks durumunu düzenlemek için çeşitli hücresel koruyucu maddeler biriktirilebilir (Catola ve ark., 2016). Mevcut çalışmada prolin, glisin betain ve karbonhidratlar gibi osmo-koruyucuların diğer bir deyişle osmotik düzenleycilerin miktarlarına odaklanılmadığı için, bazı kuraklık uygulamalarıyla birlikte gözlenen antioksidan enzim aktivitelerindeki düşüşler ve buna karşın $\mathrm{H}_{2} \mathrm{O}_{2}$ seviyelerindeki makul artışın getirdiği görece düşük MDA seviyeleri bu osmo-koruyucuların miktarındaki BAP uygulamasından kaynaklanan artışa bağlanabilir (Robert-Seilaniantz ve ark., 2010). Nitekim $A$. orientalis'te tuz (Acemi ve ark., 2017b) ve kuraklık stresleri (Acemi ve ark., 2018) altında BAP uygulaması olmamasına rağmen prolin miktarındaki önemli artışa dikkat çekmişlerdir. 

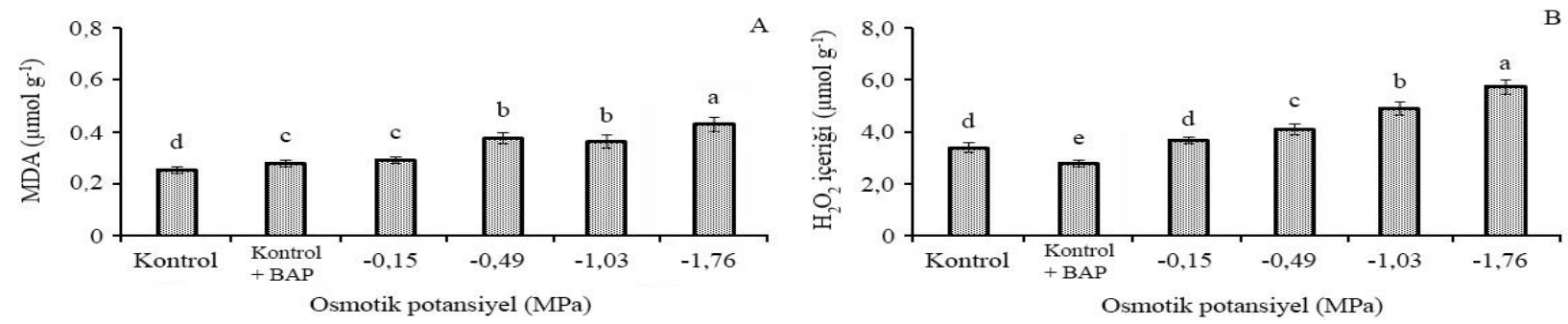

Şekil 2. Artan kuraklık stresi koşullarında $A$. orientalis sürgünlerinde (1 mg l-1 $B A P$ varlığında) $M D A(A)$ ve $\mathrm{H}_{2} \mathrm{O}_{2}(B)$ içeriğinin değişimi. Hata çubukları standart sapmayı ifade etmektedir. Aynı harfleri taşıyan değerler arasında Duncan çoklu karşılaştırma testine göre istatistiki fark yoktur $(p<0,05)$.

\section{Sonuç ve Öneriler}

$\mathrm{Bu}$ çalışma BAP destekli sürgün çoğaltımı sırasında PEG-6000 kullanılarak uygulanan kuraklık stresine maruz bırakılan $A$. orientalis bitkisinde sürgün uzunluk ve sayısının BAP ilavesiz kontrole kıyasla arttığı fakat BAP ilaveli kontrole oranla azaldığı bulunmuştur. BAP uygulamasının $\mathrm{H}_{2} \mathrm{O}_{2}$ ve buna bağlı olarak MDA üretimini orta dereceli kuraklık stresi uygulamalarında baskıladığı gözlenmiştir. Toplam POD ve CAT enzimi aktivitesini artan kuraklık stresi altında azaldığı, SOD aktivitesini ise şiddetli kuraklık stresi altında arttığı tespit edilmiştir. BAP varlığında herhangi bir stres etmeni yokken antioksidan enzim aktivitelerinin daha yüksek bulunması fakat kuraklık uygulandığında beklenenin aksine kademeli olarak azalması durumu $A$. orientalis'te BAP uygulamasının hücresel osmotik düzeneyicilerin oluşumunu artırmış olabileceği ve enzimatik olmayan bu savunma mekanizmasının antioksidan savunma sisteminden daha etkin kullanılmasına yol açabileceğini göstermektedir. Bu nedenle bitkide kuraklık stresinde BAP uygulamasının moleküler ve fizyolojik işleyişinin detaylı olarak ortaya konması gerekmektedir. Ayrıca doğadaki $A$. orientalis popülasyonlarının kuraklığa maruz kalması durumunda BAP uygulamasının kuraklığın sürgünler üzerindeki olumsuz etkilerini yatıştırabileceği düşünülmektedir.

\section{Teşekkür}

Bu çalışma, Türkiye Bilimsel ve Teknolojik Araştırma Kurumu (TÜBITAK) tarafından desteklenmiştir (113Z609).

\section{Kaynaklar}

Acemi, A., Özen, F., Kıran, R. 2012. Development of an efficient callus production protocol for Amsonia orientalis: A critically endangered medicinal plant. Eurasian Journal of Biosciences, 6: 105-112.
Acemi, A., Özen, F., Kıran, R. 2013. In vitro propagation of Amsonia orientalis Decne. from nodal segments of adult plants. Propagation of Ornamental Plants, 13: 25-32.

Acemi, A., Duruksu, G., Özen, F. 2017a. Cytostatic effects of methanolic extracts of Amsonia orientalis Decne. on MCF-7 and DU145 cancer cell lines. Notulae Botanicae Horti Agrobotanici Cluj-Napoca, 45(1): 36-42.

Acemi, A., Duman, Y., Karakuş, Y.Y., Kömpe, Y.Ö., Özen, F. 2017b. Analysis of plant growth and biochemical parameters in Amsonia orientalis after in vitro salt stress. Horticulture, Environment, and Biotechnology, 58: 231-239.

Acemi, A., Duman, Y., Karakuş, Y.Y., Özen, F. 2018. Developmental and biochemical analyses of in vitro drought stress response in ornamental European Bluestar (Amsonia orientalis Decne.). Folia Horticulturae, 30(2): 405-414.

Aebi, H. 1974. Methods of enzymatic analysis. "Alınmıştır: Catalase. (ed) Bergmeyer, H.U., Academic Press, New York, 673-675.

Anjum, S.A., Xie, X., Wang, L., Saleem, M.F., Man, C., Lei, W. 2011. Morphological, physiological and biochemical responses of plants to drought stress. African Journal of Agricultural Research, 6: 2026-2032.

Beauchamp, C.O., Fridovich, I. 1973. Isozymes of superoxide dismutase from wheat germ. Biochimica et Biophysica Acta, 317: 50-64.

Bradford, M. 1976. A rapid and sensitive method for the quantification of microgram quantities of protein using the principle of protein-dye binding. Analytical Biochemistry, 72: 248-254.

Catola, S., Marino, G., Emiliani, G., Huseynova, T., Musayev, Y., Akparov, Z., Maserti, B.E., 2016. Physiological and metabolomic analysis of Punica granatum (L.) under drought stress. Planta, 243(2): 441-449.

Doupis, G., Chartzoulakis, K., Beis, A., Patakas, A. 2011. Allometric and biochemical responses 
of grapevines subjected to drought and enhanced ultraviolet-B radiation. Australian Journal of Grape and Wine Research, 17: 3642.

Duman, Y.A., Acemi, A., Toygar, H.I.., Yüzügüllü, Y., Özen, F. 2016. Tuz stresi ve BAP varlığında Amsonia orientalis'in antioksidan enzimlerinin incelenmesi, Celal Bayar Üniversitesi Fen Bilimleri Dergisi, 12(3): 543-551.

Farooq, M., Wahid, A., Kobayashi, N., Fujita, D., Basra, S.M.A. 2009. Plant drought stress: Effects, mechanisms and management. Agronomy for Sustainable Development, 29: 185-212.

George, E.F. 2008. Plant propagation by tissue culture. Springer (3rd ed), Dordrecht.

Gurmani, A.R., Bano, A., Khan, S.U., Din, J., Zhang, J.L. 2011. Alleviation of salt stress by seed treatment with abscisic acid (ABA), 6benzylaminopurine (BA) and chlormequat chloride (CCC) optimizes ion and organic matter accumulation and increases yield of rice (Oryza sativa L.). Australian Journal of Crop Science, 5: 1278-1285.

Gürkanlı, C.T., Özkoç, İ., Aydın, E.B., Acemi, A., Özen, F. 2014. Genetic diversity of Amsonia orientalis. Biologia, 69: 742-749.

Kotov, A.A., Kotova, L.M. 2015. Role of acropetal water transport in regulation of cytokinin levels in stems of pea seedlings. Russian Journal of Plant Physiology, 62(3): 390-400.

Kumari, S., Kumar, S., Prakash, P. 2018. Exogenous application of cytokinin (6-BAP) ameliorates the adverse effect of combined drought and high temperature stress in wheat seedling. Journal of Pharmacognosy and Phytochemistry, 7(1): 1176-1180.

Mohammadkhani, N., Heidari, R. 2008. Effects of drought stress on soluble proteins in two maize varieties. Turkish Journal of Biology, 32: 23-30.

Murashige, T., Skoog, F. 1962. A revised medium for rapid growth and bioassays with tobacco tissue culture. Physiologia Plantarum, 15: 473497.

Rivero, R.M., Kojima M., Gepstein, A., Sakakibara, H., Mittler, R., Gepstein, S., Blumwald, E. 2007. Delayed leaf senescence induces extreme drought tolerance in a flowering plant. Proceedings of the National Academy of Sciences of The United States of America, 104: 19631-19636.
Robert-Seilaniantz A., Bari R., Jones, J.D.G. 2010. A Biotic or Abiotic Stress?. "Alınmıştır: Abiotic Stress Adaptation In Plants. (ed) Pareek A., Sopory S.K., Bohnert H.J., Govindjee, Springer, Dordrecht, The Netherlands, 103117.

Rulcová, J., Pospíšilová, J. 2001. Effect of benzylaminopurine on rehydration of bean plants after water stress. Biologia Plantarum, 44: 75-81.

Sedghi, M., Sharifi, R.S., Pirzad, A.R., AmanpourBalaneji, B. 2012. Phytohormonal regulation of antioxidant systems in petals of drought stressed pot marigold (Calendula officinalis L.). Journal of Agricultural Science and Technology, 14: 869-878.

Skórzyńska-Polit, E. 2007. Lipid Peroxidation in plant cells, its physiological role and changes in heavy metal stress. Acta Societatis Botanicorum Poloniae, 76(1): 49-54.

Targovnik, A.M., Cascone, O., Miranda, M.V. 2012. Extractive purification of recombinant peroxidase isozyme $c$ from insect larvae in aqueous two-phase systems. Separation and Purification Technology, 98: 199-205.

Turan, S., Tripathy, B.C. 2013. Salt and genotype impact on antioxidative enzymes and lipid peroxidation in two rice cultivars during deetiolation. Protoplasma, 250: 209-222.

Valetti, N.W., Picó, G. 2013. A friendly method for Raphanus sativus L. (wild radish) peroxidase purification by polyelectrolyte precipitation. Seperation and Purification Technology, 119: 1-6.

Wu, G.Q., Zhang, L.N., Wang, Y.Y., 2012. Response of growth and antioxidant enzymes to osmotic stress in two different wheat (Triticum aestivum L.) cultivars seedlings. Plant, Soil and Environment, 58(12): 534-539.

Xu, Q., Lu, Y., Jing, L., Cai, L., Zhu, X., Xie, J., Hu, X. 2014. Specific binding and inhibition of 6 benzylaminopurine to catalase: Multiple spectroscopic methods combined with molecular docking study. Spectrochimica Acta Part A: Molecular and Biomolecular Spectroscopy, 123: 327-335.

Yüzügüllü Karakuş, Y., Toygar, H.İ., Acemi, A., Avcı Duman, Y., Özen, F. 2018. UV-C stresinin 6benzilaminopürin varlığında çoğaltılmış Amsonia orientalis'in in vitro sürgün gelişimi ve antioksidan enzimleri üzerine etkileri. Afyon Kocatepe Üniversitesi Fen ve Mühendislik Bilimleri Dergisi, 18: 44-52. 